\title{
Methods of multi-criteria evaluation of economic efficiency of investment projects
}

\author{
Oksana Isai $^{\mathrm{a}}$, Olha Romashko ${ }^{b^{*}}$, Andriy Semenov ${ }^{c}$, Tetiana Sazonova ${ }^{\mathrm{d}}$, Ivanna Podik ${ }^{\mathrm{e}}$, Iryna Hnatenko \\ Viktoriia Rubezhanska ${ }^{g}$
}

${ }^{a}$ Kyiv National Economic University named after Vadym Hetman, Ukraine

${ }^{b}$ Kyiv National University of Trade and Economics, Ukraine

${ }^{c}$ Classic Private University, Ukraine

${ }^{d}$ Poltava State Agrarian Academy, Ukraine

e University of the State Fiscal Service of Ukraine, Ukraine

${ }^{f}$ Kyiv National University of Technologies and Design, Ukraine

${ }^{g}$ Luhansk Taras Shevchenko National University, Ukraine

\section{H R O N I C L E}

Article history:

Received: October 1, 2020

Received in revised format:

December 1, 2020

Accepted: January 4, 2021

Available online:

January 4, 2021

Keywords:

Investment

Investment project

Economic efficiency indicator

Evaluation methods

Investment decision

\section{A B S T R A C T}

In the context of globalization and fierce competition in world markets, the high level of investment activity in the country is a key to economic and innovative development. The high level of wear and tear of fixed assets in developing countries gives special relevance to solving the problem of attracting investments for production development. Hence, for the investment management system choosing an optimal variant among several available investment projects is one of the most responsible stages of ensuring the stable operation and sustainable development of an enterprise. In this regard, the aim of the article is to develop a comprehensive multi-criteria approach to choose the best investment option. The article analyzes the existing methodological approaches to assess the economic efficiency of the investment projects, identifies their advantages and disadvantages. A multi-criteria method of investment project evaluation is proposed, which is characterized by the absence of restrictions on the number of individual evaluation indicators and the possibility for the investor to determine the significance of every indicator using weights independently. The use of the proposed methodology by enterprises will improve the quality of management decisions at the stage of choosing the optimal investment option.

(C) 2021 by the authors; licensee Growing Science, Canada

\section{Introduction}

High level of investment activity is one of the factors of economic and innovative development of any country in the world, owing to the fact that without the influx of investments economic life and social development of industries, regions, countries fades, declining production, providing unemployment and social tension in society. The problem of investment inflow is foregrounded by the high level of wear and tear of fixed assets of many industrial enterprises in developing countries. It is possible to prevent the negative consequences of depreciation of enterprise assets with significant increase in the level of investment activity. At the same time, in the current economic situation, entrepreneurship cannot count on budget investments due to their numerous limitations. That is why for the investment management system the choice of the optimal option between several available investment projects is one of the most vital stages of ensuring the steady operation and development of an enterprise (Goncharov et al., 2013; Kuksa et al., 2019; Hnatenko et al., 2020). The period of return on capital investments, options for its alternative use and the additionally generated income flow of the enterprise in the future period depend on how objectively and comprehensively the investment projects are evaluated. In this regard, the development of optimal methods for evaluating the economic efficiency of investment projects becomes especially important.

\footnotetext{
* Corresponding author. Tel.: +380503445935
}

E-mail address: RomashkoOlga20@gmail.com (O. Romashko) 
Many scientists research and develop approaches to evaluat the economic efficiency of the investment projects. Thus, Liu, Hsu (2015) proposed four specific aspects of assessing economic efficiency using as an example of the investment projects for the development of cable car systems in Taiwan. In another article, Erfani and Tavakolan (2020) developed an integrated model for assessing the risks of investment projects in the field of wind energy that allows predicting the size of cash flows from investments. Clements and Si (2011), using the binary choice model, identified the determinants of the probability of success and cost-effectiveness of some investment projects for the development of natural resources in Australia. Bartošová, Majerčák, Hrašková (2015) discussed the advantages and disadvantages of using traditional evaluation methods, as well as their relationships with risk, to determine the economic efficiency of investment projects. Wei et al. (2020) proposed a flexible model for evaluating the effectiveness of investment projects, which can help oil companies evaluate their own investment projects for the development of oil sands with different characteristics of the relevant technological process in these companies. Chang et al. (2019), in order to increase the accuracy of investing in grid construction projects and prevent possible risks, proposed a method for evaluating investment projects to provide optimal decision-making in the management of these projects. Joppen et al. (2019) considered and analyzed the method of data collection for evaluation of economic efficiency of investment projects for the development of industrial production. In a scientific work, Özkır and Demirel (2012) developed a model of fuzzy linear programming to assess the economic efficiency of investment projects in the field of transport in Turkey. Aseev et al. (2005) built the optimum function of the management of investment portfolio of an innovative enterprise using various methods of estimation of investment projects. Mcadam et al. (2010) developed a model for implementing investmentdriven innovation into the activities of small and medium enterprises in the UK, using traditional methods of assessing the effectiveness of investment projects.

Paying tribute to the above studies, it is noteworthy that there is a necessity of further researches of the existing approaches to evaluat the economic efficiency of investment, identifying their shortcomings and developing a system-based integrated multi-criteria approach to choose the best investment option.

\section{Research methods}

In a modern market economy, the numbers of methods are known to assess the effectiveness of investment. The most common methods are payback period, efficiency ratio, net present value (NPV), profitability index and internal rate of return on investment (Petryk et al., 2020; Ganushchak-Efimenko et al., 2020; Samborskyi et al., 2020). At the same time, these methods, along with some positive aspects, have a number of significant shortcomings that must be taken into consideration during the analysis of investment projects (Table 1).

Table 1

Analysis of single-criteria methods of evaluating the economic efficiency of investment projects

\begin{tabular}{|c|c|c|c|c|}
\hline $\begin{array}{c}\text { The name of the method } \\
\text { and } \\
\text { brief description }\end{array}$ & Contents of the method & Legend & Advantages & Disadvantages \\
\hline $\begin{array}{l}\text { 1. Payback } \\
\text { Period (PP) } \\
\text { - the minimum time } \\
\text { interval required to recoup } \\
\text { investment costs from net } \\
\text { cash flows. }\end{array}$ & $\begin{array}{l}\text { If the amount of cash flow is } \\
\text { constant in each period of the } \\
\text { investment project, the } \\
\text { calculation formula is: } \\
\qquad P P=l_{0} / C F \text {. } \\
\text { If CF is uneven in different } \\
\text { periods of time, the value of PP is } \\
\text { determined by the sum of integer } \\
\text { and fractional components. } \\
\text { The integer part is: } \\
\qquad P P=\sum C F \\
\text { The fractional part is: } \\
D=\left(l_{0}-[C F 1+C F 2\right. \\
\left.\left.+C F_{j}\right]\right) / C F_{j}+1\end{array}$ & $\begin{array}{l}l_{0} \text { - the amount of initial } \\
\text { investment costs; } \\
C F_{t} \text { - net operating cash } \\
\text { flow; } \\
j, d \text { - integer and } \\
\text { fractional components } \\
\text { of the payback period }\end{array}$ & $\begin{array}{l}\text { 1. Allows you to } \\
\text { assess the liquidity } \\
\text { and riskiness of the } \\
\text { project, as long } \\
\text { payback means: } \\
\text { a) long-term } \\
\text { immobilization of } \\
\text { funds; } \\
\text { b) increased risk. } \\
\text { 2. Ease of use }\end{array}$ & $\begin{array}{l}\text { 1. Does not consider income } \\
\text { from investments outside the } \\
\text { payback period. } \\
\text { 2. Ignores the possibility of } \\
\text { reinvestment and the } \\
\text { temporary value of money. } \\
\text { 3. Does not have the property } \\
\text { of additivity. } \\
4 \text {. The overall profitability of } \\
\text { the project cannot be measured } \\
\text { with the isolated use of the } \\
\text { payback method. }\end{array}$ \\
\hline $\begin{array}{l}\text { 2. Account rate of return } \\
\text { (ARR) } \\
\text { - the average project ARR } \\
\text { for its lifetime is } \\
\text { compared with the } \\
\text { average investment in the } \\
\text { project. }\end{array}$ & $\begin{array}{l}A R R=\left(\sum P_{t} / n\right)+ \\
+\left(\left(l_{0}+\left[l_{0}-S A t\right]\right) / 2\right) . \\
\text { If after the end of the project it is } \\
\text { planned to receive liquidation } \\
\mathrm{CF}, \text { then its forecasted value }(\mathrm{Af}) \\
\text { should be excluded from the } \\
\text { initial amount of investments }\end{array}$ & $\begin{array}{l}P_{t}-\text { project profit; } \\
n \text { - the term of } \\
\text { investments realization }\end{array}$ & $\begin{array}{l}\text { Easy to understand } \\
\text { and includes simple } \\
\text { calculations }\end{array}$ & $\begin{array}{l}\text { 1. Does not take into account } \\
\text { the temporary value of money } \\
\text { and the possibility of } \\
\text { reinvestment of income. } \\
\text { 2. The non-monetary nature of } \\
\text { some types of expenses and } \\
\text { the related tax savings are } \\
\text { ignored. } \\
\text { 3. It is not possible to assess } \\
\text { the advantages of the projects } \\
\text { with the same ARR, but } \\
\text { different average investments }\end{array}$ \\
\hline
\end{tabular}


Table 1

Analysis of single-criteria methods of evaluating the economic efficiency of investment projects (Continued)

\begin{tabular}{|c|c|c|c|c|}
\hline $\begin{array}{c}\text { The name of the method } \\
\text { and } \\
\text { brief description }\end{array}$ & Contents of the method & Legend & Advantages & Disadvantages \\
\hline $\begin{array}{l}\text { 4. Profitability } \\
\text { Index (PI) } \\
\text { - income per unit of } \\
\text { expenditure }\end{array}$ & $\begin{array}{l}P I=P V / l_{0} \\
P V=S[C F t /(1+r)]\end{array}$ & $\begin{array}{l}\text { If } P I>1 \text {, then the } \\
\text { project should be } \\
\text { accepted; } \\
\text { if } P I<1 \text {, the project } \\
\text { should be rejected; } \\
\text { if } P I=1 \text {, then the } \\
\text { project is neither } \\
\text { profitable nor } \\
\text { unprofitable }\end{array}$ & $\begin{array}{l}\text { It is a relative } \\
\text { indicator. } \\
\text { Due to this, it is } \\
\text { convenient when } \\
\text { choosing one project } \\
\text { from a number of } \\
\text { alternatives with } \\
\text { approximately the } \\
\text { same NPV values or } \\
\text { when creating the } \\
\text { investment portfolio } \\
\text { with the maximum } \\
\text { NPV value. }\end{array}$ & $\begin{array}{l}\text { Cannot be used in the case of } \\
\text { analysis of extraordinary } \\
\text { projects that involve a } \\
\text { significant outflow of funds } \\
\text { during their implementation or } \\
\text { after their completion }\end{array}$ \\
\hline $\begin{array}{l}5 . \text { Internal } \\
\text { rate of return (IRR) } \\
\text { - discount rate that } \\
\text { compares the present } \\
\text { values of expected } \\
\text { revenues from the project } \\
\text { with the investment }\end{array}$ & $\begin{array}{l}\text { This indicator is determined from } \\
\text { the following equation: } \\
\qquad N P V=-l_{0}+\sum(C F t / \\
\qquad /(1+1 R R)=0 \text {. } \\
\text { There are the following } 4 \text { ways to } \\
\text { find } I R R \text { : } \\
\text { - - substitution method, } \\
\text { calculating } N P V \text { different values } \\
\text { of the discount rate to the value } \\
\text { when } N P V \text { changes from positive } \\
\text { to negative; } \\
\text {-using a simplified formula: } \\
\quad I R R=r 2+(r 1-r 2) \mathrm{x} \\
\mathrm{x} N P V 2 /(N P V 2-N P V 1) \text {, } \\
\text { the next inequations must be } \\
\text { followed: } \\
r 2<I R R<r 1 \mathrm{i} \\
N P V 1<0<N P V 2 \text {; } \\
\text { - applying standard values of the } \\
\text { current annuity value factor } \\
\text { (PVIFAr, n) at a constant value } \\
\text { of net cash flow }\end{array}$ & $\begin{array}{l}r 1 \text { - the value of the } \\
\text { tabulated discount rate, } \\
\text { minimizes the positive } \\
\text { value of } N P V \text {; } \\
r 2 \text { - the value of the } \\
\text { tabulated discount rate, } \\
\text { maximizes the negative } \\
\text { value of } N P V \text {; } \\
C C \text { - the price of } \\
\text { invested capital. } \\
\text { If } I R R>C C \text {, then the } \\
\text { project should be } \\
\text { accepted; } \\
\text { if } I R R<C C \text {, the project } \\
\text { should be rejected; } \\
\text { if } I R R=C C \text {, the project } \\
\text { is neither profitable nor } \\
\text { unprofitable }\end{array}$ & $\begin{array}{l}\text { In general, the } \\
\text { method is not very } \\
\text { difficult to understand } \\
\text { and is well consistent } \\
\text { with the main } \\
\text { purpose of financial } \\
\text { management - } \\
\text { increasing } \\
\text { shareholder's profits }\end{array}$ & $\begin{array}{l}\text { 1. The complexity of the } \\
\text { calculation. } \\
\text { 2. The most profitable project } \\
\text { is not always allocated. } \\
\text { 3. Contemplates an unrealistic } \\
\text { situation of reinvestment of all } \\
\text { intermediate cash receipts } \\
\text { from the project at the rate of } \\
\text { internal profitability, as one } \\
\text { part of the funds can be paid in } \\
\text { the form of dividends, and the } \\
\text { other - invested in low-yield } \\
\text { but reliable assets. } \\
\text { 4. Does not solve the problem } \\
\text { of multiplicity of the internal } \\
\text { rate of return for } \\
\text { unconventional monetary } \\
\text { projects. } \\
\text { 5. Does not take into account } \\
\text { the size of the project and, } \\
\text { therefore, the absolute value of } \\
\text { improving the welfare of the } \\
\text { company (firm, enterprise) }\end{array}$ \\
\hline
\end{tabular}

Thus, the methods of evaluating the efficiency of investment projects, shown in Table 1, have certain shortcomings, and the existing methodology of investment evaluation provides the selection of the most effective one based on a single indicator.

\section{Research results and discussion}

The presence of certain shortcomings of modern methods of assessing the economic efficiency of investments significantly complicates the choice of the optimal version of an investment project, which is clearly shown in the example of the data presented in Table 2.

\section{Table 2}

Estimates of evaluation indicators of hypothetical investment projects

\begin{tabular}{|c|c|c|c|c|c|c|}
\hline $\begin{array}{l}\text { Indicators of economic } \\
\text { efficiency of } \\
\text { investment projects }\end{array}$ & $\mathrm{X}_{1}$ & $\mathrm{X}_{2}$ & $\begin{array}{l}\text { Projects } \\
\mathrm{X}_{3}\end{array}$ & $\mathrm{X}_{4}$ & $\mathrm{X}_{5}$ & $\begin{array}{c}\text { The optimal } \\
\text { project }\end{array}$ \\
\hline Payback Period (PP) & 0,3 & 0,3 & 0,396 & 0,6 & 0,804 (maximum) & $\mathrm{X}_{5}$ \\
\hline $\begin{array}{l}\text { Account rate of return } \\
\text { (ARR), } \%\end{array}$ & 66,0 (maximum) & 63,96 & 54,0 & 33,96 & 27,96 & $\mathrm{X}_{3}$ \\
\hline NPV, $\$$ & 669,48 & $\begin{array}{c}723,96 \\
\text { (maximum) }\end{array}$ & 673,2 & 428,16 & 273,6 & $\mathrm{X}_{2}$ \\
\hline Profitability index (PI) & 1,752 & 1,8 & 1,764 & $\begin{array}{c}1,836 \\
\text { (maximum) }\end{array}$ & 1,176 & $\mathrm{X}_{4}$ \\
\hline $\begin{array}{l}\text { Internal rate of return } \\
\text { (IRR), } \%\end{array}$ & 27,24 & 30,0 & $\begin{array}{c}32,52 \\
\text { (maximum) }\end{array}$ & 30,36 & 21,72 & $\mathrm{X}_{1}$ \\
\hline
\end{tabular}

According to Table 2, five hypothetical investment projects were selected for the evaluation, each of which is proved to be optimal due to the presence of the only one indicator of economic efficiency with maximum value. Thus, according to the payback period, the optimal project is $\mathrm{X}_{5}$, according to the efficiency ratio $-\mathrm{X}_{1}$, according to NPV $-\mathrm{X}_{2}$, according to the profitability $-\mathrm{X}_{4}$, according to the internal rate of return $-\mathrm{X}_{3}$. It is a typical situation that choosing the best investment option creates significant uncertainty when choosing the most successful capital investment option. To solve this problem, we 
consider using the method of comprehensive multi-criteria assessment of economic efficiency of investment projects as the most appropriate one.

From the point of view of the solved problem context, applying the method of an ideal point is the most successful among the existing methods of multi-criteria optimization. Thus, in general, the algorithm of comparative rating assessment of the economic efficiency of the investment project can be represented as a sequence of the following steps:

1. The source data is presented in the form of a matrix $\left(a_{i j}\right)$ (table 3$)$, where the rows are recorded numbers of indicators $(i=$ $1,2,3 \ldots n)$, and the columns are the projects' numbers $(j=1,2,3 \ldots m)$.

2. For each indicator, the maximum value is found and entered in the column of the reference project $(m+1)$.

3. Initial indicators of the matrix $a_{i j}$ are standardized for the relevant indicator of the reference project by the formula (1):

$$
\mathrm{X}_{i j}=\frac{a_{i j}}{\operatorname{maxa}_{i j}}
$$

where $\mathrm{X}_{i j}$ - standardized indicators of economic efficiency of $\mathrm{j}$ project;

$a_{i j}$ - initial indicators of the economic efficiency of the project.

4. For each analyzed project, the value of its rating $\left(R_{j}\right)$ is determined by the formula (2):

$$
R_{j}=\sqrt{K_{1}\left(1-x_{1 j}^{2}\right)^{2}+\cdots+K_{n}\left(1-x_{n j}^{2}\right)^{2}}
$$

where $K_{1}, K_{2}, \ldots K_{n}$ - weights of the indicators assigned by the expert.

Thus, the evaluation of the project is carried out by comparing it for each indicator of economic efficiency with the reference project, which has the best results on all comparable parameters.

Table 3

\begin{tabular}{|c|c|c|c|c|c|c|c|}
\hline \multirow{2}{*}{$\begin{array}{l}\text { Indicators of economic } \\
\text { efficiency of } \\
\text { investment projects }\end{array}$} & \multicolumn{5}{|c|}{ Projects } & \multirow{2}{*}{$\begin{array}{l}\text { Reference } \\
\text { project }\end{array}$} & \multirow{2}{*}{$\begin{array}{l}\text { Weigh } \\
\mathrm{t}\end{array}$} \\
\hline & $\mathrm{X}_{1}$ & $\mathrm{X}_{2}$ & $\mathrm{X}_{3}$ & $\mathrm{X}_{4}$ & $\mathrm{X}_{5}$ & & \\
\hline Payback Period (PP) & 0,3 & 0,3 & 0,396 & 0,6 & 0,804 (maximum) & 0,804 & 0,14 \\
\hline $\begin{array}{l}\text { Account rate of return } \\
\text { (ARR), } \%\end{array}$ & $\begin{array}{c}66,0 \\
\text { (maximum) }\end{array}$ & 63,96 & 54,0 & 33,96 & 27,96 & 66,0 & 0,10 \\
\hline $\mathrm{NPV}, \$$ & 669,48 & $\begin{array}{c}723,96 \\
\text { (maximum) }\end{array}$ & 673,2 & 428,16 & 273,6 & 723,96 & 0,33 \\
\hline Profitability index (PI) & 1,752 & 1,8 & 1,764 & 1,836 (maximum) & 1,176 & 1,836 & 1,53 \\
\hline $\begin{array}{l}\text { Internal rate of return } \\
\text { (IRR), } \%\end{array}$ & 27,24 & 30,0 & 32,52 (maximum) & 30,36 & 21,72 & 32,52 & 0,24 \\
\hline Project rating $(\mathrm{R})$ & 0,252 & 0,238 & 0,203 & 0,297 & 0,482 & & \\
\hline Ranking (Rank) & 3 & 2 & 1 & 4 & 5 & & \\
\hline
\end{tabular}

The results of choosing the best option for an investment project

The analysis significantly reduced the uncertainty in making an investment decision and showed that the most effective one of the proposed hypothetical investment projects is X3. The advantages of the proposed rating technique include the absence of restrictions on the number of individual indicators of economic efficiency of the project and the fact that the investor determines their significance using weights. However, the final choice of the optimal investment project is left to the person who makes the appropriate decisions. Thereby, the proposed method of multi-criteria evaluation of investment efficiency allows improving the quality of management decisions during choosing investment projects and can be used by various companies at the stage of choosing the best investment option.

\section{Conclusions}

As a result of the study, it was found that providing a high level of investment activity is the basis of the growth of business activity, which is a guarantee of quantitative and qualitative growth of production processes. It also increases the investment attractiveness of economy as a whole. In this case, the efficiency of investment activities is ensured by choosing the optimal investment project that would reduce the cost of goods (works, services) produced, improve quality, expand the range of products, increase enterprise income, eliminate production and financial risks.

It is possible to determine the most cost-effective investment project using a multi-criteria method of project evaluation, which is characterized by no restrictions on the number of individual evaluation indicators and the possibility of self-determination of the significance of each indicator using weights. In this regard, the use of the proposed methodology by enterprises will improve the quality of management decisions at the stage of choosing the optimal investment option. 


\section{References}

Aseev, S., Hutschenreiter, G., Kryazhimskiy A., \& Lysenko, A. (2005). A dynamic model of optimal investment in research and development with international knowledge spillovers, Mathematical and Computer Modelling of Dynamical Systems, 11(2), 125-133. https://doi.org/10.1080/1387395050500067361

Bartošová, V. Majerčák, P. \& Hrašková, D. (2015).Taking Risk into Account in the Evaluation of Economic Efficiency of Investment Projects: Traditional Methods, Procedia Economics and Finance, 24, 68-75.https://doi.org/10.1016/S22125671(15)00614-0

Chang, Y., Liu, C., Liu, M., Liu, W., Liu, Z., Zhang H., \& Zheng, Y. (2019). Differentiation degree combination weighting method for investment decision-making risk assessment in power grid construction projects, Global Energy Interconnection, 2(5), 465-477. https://doi.org/10.1016/j.gloei.2019.11.022

Clements, K. W., \& Si, J. (2011). The investment project pipeline: cost escalation, lead time, success, failure and speed, Australian Journal of Management, 36(3), 317-348. https://doi.org/10.1177/0312896211427322

Erfani, A., \& Tavakolan, M. (2020). Risk Evaluation Model of Wind Energy Investment Projects Using Modified Fuzzy Group Decision-making and Monte Carlo Simulation, Arthaniti: Journal of Economic Theory and Practice. https://doi.org/10.1177/0976747920963222

Ganushchak-Efimenko, L., Hnatenko, I., Kozhushko, R., Rębilas, R., Rubezhanska, V. \& Krakhmalova, T. (2020). Optimization models of investment management in the activities of innovative enterprises, Management Theory and Studies for Rural Business and Infrastructure Development, 42(3), 225-234. https://doi.org/10.15544/mts.2020.22

Goncharov, V.M., Zos-Kior, M. \& Rakhmetulina Z. (2013). The investment component of ukrainian agrarian enterprises' development in conditions of land reform, Actual Problems of Economics, 10(148), 118-125.

Hnatenko, I., Kuksa, I., Naumenko, I., Baldyk, D. \& Rubezhanska, V. (2020). Infrastructure of innovation enterprise: features of formation and regulation in modern market conditions, Management Theory and Studies for Rural Business and Infrastructure Development, 42(1), 97-104. https://doi.org/10.15544/mts.2020.10.

Hnatenko, I., Orlova-Kurilova, O., Shtuler, I., Serzhanov, V. \& Rubezhanska, V. (2020). An Approach to Innovation Potential Evaluation as a Means of Enterprise Management Improving, International Journal of Supply and Operations Management, 7(1), 112-118. https://doi.org/10.22034/ijsom.2020.1.7.

Joppen, R., Kühn, A., Hupach, D. \& Dumitrescu, R. (2019). Collecting data in the assessment of investments within production, Procedia CIRP, 79, 466-471. https://doi.org/10.1016/j.procir.2019.02.126

Kuksa, I., Hnatenko, I., Orlova-Kurilova, O., Moisieieva, N. \& Rubezhanska, V. (2019). State regulation of innovative employment in the context of innovative entrepreneurship development, Management Theory and Studies for Rural Business and Infrastructure Development, 41(2), 228-236. https://doi.org/10.15544/mts.2019.19

Kuksa, I., Shtuler, I., Orlova-Kurilova, O., Hnatenko, I. \& Rubezhanska, V. (2019). Innovation cluster as a mechanism for ensuring the enterprises interaction in the innovation sphere, Management Theory and Studies for Rural Business and Infrastructure Development, 41(4), 487-500. https://doi.org/10.15544/mts.2019.39.

Liu, H.-L., \& Hsu, W.-L. (2015). Framework for assessing cable car construction investment projects: Examining investment projects in Taiwan, Advances in Mechanical Engineering. https://doi.org/10.1177/1687814015620087

Mcadam, R., Moffett, S., Hazlett, S. \& Shevlin, M. (2010). Developing a model of innovation implementation for UK SMEs: A path analysis and explanatory case analysis, International Small Business Journal, 28, $195-214$. https://doi.org/10.1177/0266242609360610

Özkır, V. \& Demirel, T. (2012). A fuzzy assessment framework to select among transportation investment projects in Turkey, Expert Systems with Applications, 39(1), 74-80. https://doi.org/10.1016/j.eswa.2011.06.051

Petryk, O., Semenov, A., Hnatenko, I., Samiilenko, A., Rubezhanska V. \& Patsarniuk, O. (2020). Conceptual model for assessing the investment attractiveness of innovative projects of industrial enterprises, Accounting, 6(7), 1345-1350. https://doi.org/10.5267/j.ac.2020.8.015

Samborskyi, O., Isai, O., Hnatenko, I., Parkhomenko, O., Rubezhanska V. \& Yershova, O. (2020). Modeling of foreign direct investment impact on economic growth in a free market, Accounting, 6(5), 705-712. https://doi.org/10.5267/j.ac.2020.6.014.

Wei, Y., Qiao, L., Jiang, S-M. \& Lv, X. (2020). A decision-making approach considering technology progress for investment in oil sands projects: An empirical analysis in Canada, Journal of Petroleum Science and Engineering, 195. https://doi.org/10.1016/j.petrol.2020.107741 
(C) 2020 by the authors; licensee Growing Science, Canada. This is an open access article distributed under the terms and conditions of the Creative Commons Attribution (CC-BY) license (http://creativecommons.org/licenses/by/4.0/). 